\title{
On the hypothesis of dioicous - monoicous species pairs in the Mniaceae (Bryophyta); morphology, sexual condition and distiribution
}

On the hypothesis of dioicous - monoicous species pairs in the Mniaceae (Bryophyta); morphology, sexual condition and distiribution. - Acta Mus. Siles. Sci. Natur., 68: 67-81, 2019.

\begin{abstract}
Some early observations seemed to show that, in the Mniaceae, the doubling of the chromosome set affects a change from dioicous to monoicous condition, larger size of the gametophyte including larger leaf cell size, and to a wider range of the monoicous counterpart. The Mniaceae taxa are divided into four groups based on their sexual condition and morphology. 1. Dioicous - monoicous counterparts which can be distinguished by morphological characters, 2. Dioicous - monoicous taxa which have no morphological, deviating characters, 3. Monoicous species mostly with diploid chromosome number for which no dioicous counterpart is known, and 4. The taxa in Mniaceae with only dioicous plants. Most of the monoicous species of the Mniaceae have wide ranges, but a few of them are endemics in geographically isolated areas. The dioicous species have either a wide holarctic range or a limited range in the forested areas of temperate and meridional North America, Europe and SE Asia, or in subtropical Asia. Some of the monoicous species are evidently autodiploids and a few of them are allopolyploids from cross-sections of two species. Quite recently, several new possible dioicous - monoicous relationships have been discovered.
\end{abstract}

Key words: allopolyploids, autopolyploids, Cinclidium, Cyrtomnium, characters, diploids, floristic elements, haploids, Leucolepis, Mnium, new combination, Orthomnion, phytogeography, Plagiomnium, Pseudobryum, Rhizomnium, taxonomy, Trachycystis, number of species, polyploids, ranges

\section{Introduction}

The dioicous - monoicous species pairs in the Mniaceae were discovered by Lowry (1948). He proposed four monoicous - dioicous pairs (see below). The idea was that the doubling of the chromosome set causes a monoicous condition of the plant, a larger size and larger leaf cells. Wettstein's (1924, 1938, 1942, Wettstein \& Staub 1942) experiments gave some grounds to this hypothesis. He had produced experimentally diploid Funaria hygrometrica Hedw. and diploid new taxon, Bryum corrensii Wettst. The diploid plants showed gigantism in both the cell size and the plant body as a whole. Koponen (1967, 1971a, 1973a), Bowers (1969a,b, 1980), Mogensen (1973) and Koponen and Nilsson (1978) discussed on the topic and proposed changes and additions to Lowry's concept.

Koponen (1981a) examined Lowry's voucher specimens and found that many of them were not correctly identified. Wyatt (1985) confirmed Koponen's identifications and reviewed the earlier studies on the topic. Later R. Wyatt, in many papers (Wyatt et al. 1988, 1992, 1993a, b, 2013, Wyatt \& Odrzykoski 1989, 2012), returned to the topic and showed that although some of the species pairs seem to be autopolyploids, some of them actually are allopolyploids caused by cross-sections between species.

The moss family Mniaceae, in the sense of Koponen (1968a, 2017, Koponen \& Sun 2017), has 74 species + Ciclidium minutifolium (Koponen \& Ignatova 2018) worldwide. In this paper, I summarize the studies of the dioicous - monoicous species pairs of the Mniaceae and try to evaluate the morphological characters and phytogeography useful in separating these pairs of taxa. The world ranges of taxa and floristic elements are reviewed in relation to their monoicous or dioicous sexuality. 
The chromosome numbers in the lists below are from Bowers (1980) and Fritsch (1982), and later counts from "Index to plant chromosome numbers" 1972-2006. The count for Plagiomnium floridanum is according to Wyatt \& Odrzykoski (2012). The world ranges are from Koponen (2017). The author abbreviations are given on the lists below.

\section{Lowry's (1948) dioicous - monoicous species pairs}

The dioicous - monoicous species pairs within the traditional Mniaceae recognized by Lowry (1948) were:

Mnium affine Funck

M. cuspidatum Hedw.

M. punctatum Hedw.

M. orthorrhynchum auct.

(= M. thomsonii Mitt.)

n ${ }^{7}+9$
6
6
7
6

M. medium Bruch \& Schimp.

M. cuspidatum Hedw.

M. pseudopunctatum Bruch \& Schimp.

M. marginatum (Dicks.) P. Beauv. 2n, monoicous

12

12

14

12

However, the species pairs Lowry proposed do not hold, since his material was partly misidentified (Koponen 1981a, Wyatt 1985). Also, the morphological characters such as laminal cell size or shape do not fit in all pairs.

According to the prevailing North American tradition, Lowry (1947) named his first dioicous counterpart as Mnium affine (Plagiomium a.). The voucher specimens were identified as Plagiomnium ellipticum (Koponen 1981a). P. ellipticum is not a convenient counterpart of $P$. medium. $P$. ellipticum has wider bipolar range than $P$. medium, which is rather strictly delimited to boreal zone of the northern hemisphere (Koponen 1971a, 2014a). The shape of laminal leaf cells and teeth of leaf border are different. A character of P. ellipticum, which hardly has connection with the number of chromosomes, is the non-decurrent leaves. All the other species of Plagiomium section Rosulata have decurrent leaf bases (Koponen 1971a). Only two other species of Plagiomnium, $P$. rostratum and $P$. succulentum in the section Rostrata, have non-decurrent leaves. The loss of decurrency of leaf bases must be a result of a long-lasting evolutionary history.

Lowry (1948) discovered that in American Mnium cuspidatum (Plagiomnium c.) the chromosome numbers 6 and 12 occur. This was confirmed by Wyatt \& Odrzykoski (2012, see below under $P$. floridanum).

Lowry's (1948) dioicous - monoicous pair Mnium punctatum (Rhizomnium p.) and Mnium pseudopunctatum (Rhizomnium p.) have differences in many characters, which hardly can be caused by the doubling of the chromosomes. They have different rhizoid topography. $R$. punctatum has only axillary macronemata while both macronemata and micronemata are present in $R$. pseudopunctatum (Koponen 1968b, 1971b, 1973a, 2014b). The capsules differ, $R$. pseudopunctatum has a \pm globose, brownish capsule and brown peristome with less than 20 lamellae of the outer peristome teeth, while the capsule of $R$. punctatum is elongate, yellowish or pale and the number of lamellae is more than 20 (Koponen 1968b, 2014b). The analyses based on DNA characters (Koponen \& Sun 2017) showed that Rhizomnium horikawae, which is closely related to $R$. punctatum, is distant from $R$. pseudopunctatum. Koponen \& Sun (2017) placed them in different sections of Rhizomnium, R. punctatum in the section Rhizomium, and $R$. pseudopunctatun in the section Macromnium.

Mnium orthorrhynchum auct. (= M. thomsonii Mitt.) and $M$. marginatum could be a species pair, as Lowry proposed. The leaf cells in $M$. thomsonii are smaller than the cells of $M$. marginatum, and both are calcicole species. However, the shape of laminal cells and the leaf areolation as a whole are different. $M$. thomsonii has \pm quadrate or isodiametric laminal cells with firm cell walls and the cell size is uniform, best observed by comparing the laminal cells near the costa and at the leaf border. In M. marginatum the laminal cells near the costa are 
distinctly larger than the cells at leaf border, shortly elongated to rhomboidal and \pm thick-walled with distinct trigones. The teeth of the dorsal costa are numerous in $M$. thomsonii and the leaf marginal teeth are sharp, while the teeth of costa are few or absent in M. marginatum, and its leaf marginal teeth are smaller and blunt. $M$. lycopodioides could more probably be the dioicous counterpart of M. marginatum, but see below under Mnium marginatum.

Concluding: The dioicous - monoicous species pairs proposed by Lowry (1948) do not fulfill the morphological nor phytogeographical requirements of dioicous - monoicous species pairs in the Mniaceae, except the pair Plagiomnium cuspidatum $(\mathrm{n}=6)-P$. cuspidatum $(\mathrm{n}=$ 12).

\section{Sexual condition and morphology in the species of the Mniaceae}

On the basis of morphology, the dioicous - monoicous taxa in the Mniaceae can be divided into two groups:

1. Morphologically differing pairs

2. Morphologically similar monoicous and dioicous taxa

However, the majority of taxa in the Mniaceae do not show the dioicous - monoicous partnership:

3. Species of which only monoicous plants are known

4. Species of which only dioicous plants are known

\section{Morphologically differing monoicous - dioicous species pairs}

Cinclium arcticum (Bruch \& Schimp.)

Schimp.

C. minutifolium Broth.

Plagiomnium floridanum R. Wyatt

\& Odrzykoski

n $\delta^{\top}+$

2n, monoicous

$P$. insigne (Mitt.) T.J. Kop.

(or P. ellipticum $\times$ P. insigne)

P. maximoviczii (Müll. Hal.) T.J. Kop.

Rhizomnium gracile T.J. Kop.

7
-
6
7

6,7
7

C. stygium $\mathrm{Sw}$.

C. subrotundum Lindb.

14

14

P. cuspidatum (Hedw.) T.J. Kop. 12

P. medium (Bruch. \& Schimp.) T.J. Kop. 12

P. medium

12

P. rhynchophorum (Hook) T.J. Kop.

12

$7 \quad$ R. pseudopunctatum (Bruch \& Schimp.) T.J. Kop. 13, 14

These dioicous - monoicous species pairs can be separated from each other not only by the sexual condition but also by morphologic characters. In most cases synoicous plants are stronger and taller and their laminal cells are larger than in their dioicous counterparts. Most of the synoicous plants have wider ranges than their haploid and dioicous pairs, and the ranges are partly sympatric. The specific status has been generally accepted to these sister species. Some additions to their taxonomy and ranges are made here.

Cinclium arcticum - C. stygium

Mogensen (1973) studied the morphology and phytogeography of the species of Cinclidium and came to the conclusion that Cinclium arcticum - C. stygium are a species pair. They fulfil the morphological and geographical prerequisites of species pairs. C. arcticum is smaller in size and its leaf cells are also smaller. It is a circumpolar, high arctic - oroarctic species of the northern hemisphere while $C$. stygium has a wide-ranging circumpolar distribution in the boreal to arctic regions of the northern hemisphere and is bipolar (Mogensen (1973). Both of them grow in moist to wet habitats such as bogs and marshes, but C. arcticum is more restricted to calcareous or eutrophic subsoil. According to Wyatt et al. (2013) C. stygium may be an allopolyploid origin from $C$. arcticum and $C$. latifolium, but it is also possible that C. stygium is an autopolyploid, most likely of $C$. arcticum. Pineiro et al. (2012) did not rule out this possibility. 


\section{Cinclidium minutifolium - C. subrotundum}

Koponen and Ignatova (1918) accepted Cinclidium minutifolium Broth., which on the basis on the elongated macronematous rhizoid apparatus is a species of Cinclidium (Koponen \& Ignatova 2018, fig. 247 E). It has similar orbicular leaf shape as C. subrotundum, but has unistratose leaf border against bistratose in C. subrotundum. The dioicous sexual condition and smaller leaf cells than in $C$. subrotundum and smaller but partly sympatric range fulfill the prerequisites of species pair relationship. According to Mogensen (1973) and Koponen and Ignatova (2018), Cinclidium subrotundum has a circumpolar holarctic range and C. minutifolium occurs in arctic Asia and northern European Russia (Koponen \& Ignatova 2018). However, the relationship of these taxa still needs genetic and sequence confirmation. It may be mentioned that Wyatt et al. (2013) discovered an unknown "Cinclidium species A" from Alaska, different from other four species accepted e.g. by Mogensen (1973). Also, Pineiro et al. (2013) discovered an unknown Cinclidium, which according to M. Ignatov (pers. comm.) agrees with $C$. minutifolium.

\section{Plagiomnium floridanum - P. cuspidatum}

Bowers (1969a) proposed that Mnium cuspidatum (= Plagiomnium c.) and M. trichomanes Mitt. (= Plagomnium acutum) seem to be a natural species pair. Plagiomnium acutum has smaller laminal cell size (Koponen 1981b, diagram in fig. 20). Also, the leaf and cell sizes of many voucher specimens of chromosome counts of $P$. acutum $(\mathrm{n}=6)$ and P. cuspidatum $(\mathrm{n}=12)$ differ clearly (Koponen 1981b, diagram in fig. 21). The study includes Schornherst specimen from Florida, for which Lowry (1948) published the chromosome count $\mathrm{n}=6$. In the diagram, the Schonherst specimen differs distinctly from P. acutum and less clearly from $P$. cuspidatum. The range of $P$. acutum is limited to SW Asia (Koponen 1981b, 2014a, c) and, accordingly, smaller than the range of circumpolar, holarctic P. cuspidatum. However, the phylogenetic study by Koponen \& Sun (2017) proposed that instead of $P$. cuspidatum, the specific pair counterpart of $P$. cuspidatum is $P$. floridanum, as was already assumed by Wyatt and Odrzykoski (1998, 2012). P. floridanum has a limited range in North America in Florida, Georgia and Mississippi. P. floridanum is a calcicole, and it can be hypothetized that the change to more acid substrates, together with secured fertilization, favored the new diploid P. cuspidatum to spread to new territories.

\section{Plagiomnium insigne - P. medium}

This pair fulfils the characters of a dioicous - monoicous species pair (Koponen 1967, 1971a). The chromosome set is double in P. medium, its laminal cells are larger, and P. medium has a circumpolar holarctic range, while $P$. insigne is an endemic of western North America (Koponen 1971a). Their laminal cell shape is \pm isodiametric and with distinct trigones. Leaf marginal teeth are similar, large, sharp and formed by one or two cells and projecting towards the leaf apex. In the other dioicous species of Plagiomnim section Rosulata the leaf cells are elongated with \pm firm walls, and their leaf marginal teeth, except $P$. ellipticum, are formed by (1)2-4 cells projecting to different directions (Koponen 1971a, Jia \& He 2014). The substrates of $P$. insigne and $P$. medium are similar (Koponen 1971a).

However, Wyatt et al. $(1988,1992)$ presented that the electrophoretic patterns witness that Plagiomnium medium is an allopolyploid originating from the cross-section between Plagiomnum ellipticum $\times$ P. insigne. According to Koponen (1971a: 360), P. insigne, P. medium and $P$. rugicum (Brid.) T.J. Kop. (= P. ellipticum) are united by the acute leaf apex, teeth of leaf margin with 1 or 2 sharp cells, and laminal cells which are near to being isodiametric, although in the last respect $P$. ellipticum deviates from the other two species. $P$. ellipticum differs from $P$. insigne and $P$. medium clearly, e.g. having shorter and smaller teeth of leaf margin than any 
other taxon of the section (except $P$. medium ssp. curvatulum) and especially in the absence of decurrent leaf bases. Accordingly, when observed from the morphological point of view, the possible allopolyploid $P$. medium has inherited more characters from $P$. insigne than from P. ellipticum. Also, the wide ecological amplitude of $P$. ellipticum in many kinds of wet to moist, acid to eutrophic habitats and substrates changed to more uniform habitats on moist to mesic forest soils. The ranges of $P$. insigne and $P$. ellipticum are not sympatric, but may have been, since $P$. ellipticum is bipolar occurring in S Chile and S Argentina.

McIntosh and Newmaster (2014a) reported one collection of Plagiomnium medium from British Columbia, which is dioicous and has larger leaves and laminal cells than the other populations of $P$. medium, suggesting that it could possibly be an undescribed species. I have seen one similar specimen (male plants) collected in South Finland. Since these two finds were from widely distant localities, they may simply represent an accidental phenomenon not worth taxonomic recognition. A similar case is dioicous Mnium arizonicum $(\mathrm{n}=6)$ and M. saximontanum $(\mathrm{n}=12)$, which, in spite of the double chromosome number, is dioicous (Bowers 1969b). Koponen (1974a) synonymized these taxa and $M$. saximontanum was not mentioned by McIntosh and Newmaster (2014b).

\section{Plagiomnium maximoviczii - P. rhynchophorum}

Synoicous Plagiomnum rhynchophorum has larger laminal leaf cells than dioicous P. maximovizii. They fulfil the prerequisite of a díoicous - synoicous pair as to their distribution areas. $P$. maximoviczii has SE Asiatic range while P. rhynchphorum is pansubtropical and present in SE Asia, Africa and South America, with disjunct occurrences in southern Appalachians and Hawai'i in U.S.A (Koponen 1972a, 1979, 1981c, 1982c). They grow in forest sites on various substrates (Koponen 1972a, 1974b, 2014c).

In Plagiomnium section Rostrata, the three synoicous species are Plagiomnim rostratum, P. rhynchophorum and P. novae-zealandiae, and dioicous species number six (Koponen 1972a, 1982a). Koponen (1982a) hypothetized on the phylogeny of the species in the section Rostrata, and concluded that $P$. maximoviczii and $P$. rhynchophorum are close relatives by having similar distinct juxtacostal cells and long teeth of leaf margin formed by (1)2-4 cells (at least in welldeveloped fertile plants). Moreover, they both have long-decurrent leaves. The leaves in $P$. rostratum are non-decurrent (populations with short leaf decurrences occur in the Baikal area in Siberia) and the teeth of leaf margin are smaller and formed by one blunt cell. In the phylogenetic analysis by Koponen and Sun (2017) P. maximoviczii and $P$. rhynchophorum form a pair distant from the other taxa (P. integrum, $P$. succulentum) of the section Rostrata, which were included in their study. Harris (2008) could not present any clear-cut solution on the relationships of the taxa in the section Rostrata. In two of his cladograms $P$. maximoviczii is a sister species of $P$. rostratum and $P$. novae-zealandiae, but at the same time $P$. maximoviczii and $P$. rhynchophorum are in the same glade with $P$. integrum and $P$. vesicatum. As to $P$. novaezealandiae, see below.

\section{Rhizomnium gracile - R. pseudopunctatum}

Dioicous Rhizomnium gracile and monoicous $R$. pseudopunctatum fullfil the prerequisities of a dioicous - monicous species pair. $R$. gracile is smaller and has a boreal, N. American range extending to easternmost Asia (Koponen \& Afonina 1992, Koponen \& Ignatova 2018), with a single locality in Europe (Koponen 2015). R. pseudopuncatum has much wider arctic to boreal continuously holarctic range. Also, they both grow in \pm eutrophic swamp and fen habitats on wet peat or muddy soil. Both of them have a globose capsule and the peristomes are similar: brown and less than 20 lamellae on the outer peristome teeth. This separates them from all other species of Rhizomnium, which have elongated, pale capsule and exothecial teeth are yellow and have more than 20 lamellae (Koponen 1968b, 1973a, 2014b). Bowers (1969a) thought that 


\section{Rhizomnium magnifolium $\widehat{\partial} \bigcirc-R$. magnifolium, monoicous}

The synoicous plants of Rhizomnium magnifolium (as $R$. perssonii T.J. Kop.) were first identified from Taiwan (Koponen 1971c) and when material with sporophytes could be studied from the Himalayan area (Koponen 2014b) the morphological identity of dioicous and monoicous plants was obvious. The synoicous race of Rhizomnium magnifolium ranges from Taiwan to the Himalayas (Koponen 2014b), while the dioicous race is a holarctic circumpolar taxon (Koponen 1968b, 1971c, 1973a, Koponen \& Afonina 1992, Koponen \& Ignatova 2018). Both dioicous and synoicous specimens were included in the analysis by Koponen \& Sun (2017) and showed close relationship.

\section{Species with only monoicous plants}

Mnium marginatum (Dicks.) P. Beauv. M. spinulosum Bruch \& Schimp.

Plagiomnium curvatulum (Lindb.) Schljakov

P. drummondii (Bruch \& Schimp.) T.J. Kop.

P. novaezealandiae (Col.) T.J. Kop.

P. rostratum (Schrad.) T.J. Kop.

P. venustum (Mitt.) T.J. Kop. 2n range

12 circumpolar holarctic

8 circumpolar holarctic

12 circumpolar holarctic

6 circumpolar holarctic

14 Australia, New Zealand

12 disjunctively holarctic

12 Pacific N America

This group is formed by synoicous species, which have no morphologically similar dioicous counterpart. The explanation for this could be that the doubling of chromosomes resulting in synoicy confirmed the fertilization and the continuous production of spores. The new synoicous plant had the opportunity to spread to different areas and substrates and to adapt to climatic changes. The dioicous ancestor did not have this possibility and became extinct. The wide ranges of Mnium marginatum, $M$. spinulosum, $M$. drummondii and Plagiomnium rostratum concur with this hypothesis. $P$. venustum and $P$. novae-zealandiae remained geographically isolated. Of $P$. curvatulum, see below.

\section{Mnium marginatum}

Bowers (1969) proposed that Mnium ambiguum H. Müll. (= M. lycopodioides) and Mnium marginatum form a species pair. They seem to fulfil the prerequisite of a dioicous - monoicous species pair, M. lycopodioides has smaller leaf cells than M. marginatum. However, the shape of leaf cells is not quite identical. M. lycopodioides in general has \pm isodiametric to slightly elongated, thin-walled laminal cells with distinct trigones, while the cells in M. marginatum tend to be relatively longer with thicker walls, best seen in the cells close to the costa. The characters not fulfilling the demands of species pairs are the teeth of leaf margin and costa: $M$. lycopodioides has sharp teeth while the teeth of leaf margin in M. marginatum are blunt and the costa is smooth or there are a few blunt teeth. This does not fit to the theory of dioicous monoicous species pairs; compared with Plagiomium insigne - P. medium and P. floridanum$P$. cuspidatum in which the teeth characters are similar. One character present in many populations of $M$. marginatum is the long cuspidate leaf apex, which is gradually acute in M. lycopodioides. Also, the ranges of these two taxa do not support their species pair connection. Both of them are holartic, but the range of $M$. marginatum is more limited. It has \pm continuous range in North America and Europe but in Asia it is rare in China and absent from Japan. M. lycopodioides has wider range in North America (Koponen 1979, map as M. ambiguum), North Asia (Koponen \& Ignatova 2018) and SE Asia (Koponen 2014c,) than the range of M. marginatum. On the contrary, in Scandinavia (Söderström et al. 1998) and Britain (Blockeel et al. 2014), and obviously in other parts of Europe M. lycopodioides is rare (Frey et al. 1995), occurring only in boreal and oroboreal areas, while M. marginatum is temperate. 
However, M. lycopodioides is heterogeneous in some characters such as the size and the number of the teeth on the costa. In western North America large-sized plants, known as M. umbratile Mitt. occur, while in SW Asia plants of some of populations are much smaller (M. laevinerve Cardot). In Japanese populations the number of teeth on the costa varies, and plants with a smooth costa exist (Koponen 2014c). M. lycopodioides grows in many mesic substrates (Koponen 2014c) while M. marginatum is a calcicole. A similar difference is absent in the pairs Plagiomium insigne - P. medium and P. maximoviczii - P. rhynchophorum.

In this connection it may be relevant to remind that a dioicous population of Mnium marginatum, named as M. riparium Mitt., has once been found in Britain (Koponen 1980b).

\section{Mnium spinulosum}

Mnium spinulosum has the chromosome number 8, differing of that of other species of Mnium. It has a strong leaf border, and teeth of leaf margin and costa are similar to those in M. spinosum. The laminal cell characters do not support their dioicous - monoicous species pair relationship, neither the chromosome number of $M$. spinosum which is 6 . The laminal cells in $M$. spinulosum are \pm isodiametric and not in rows. The leaf cells in $M$. spinosum are elongated and arranged in diagonal rows from costa to border. $M$. spinulosum has wider holarctic mainly boreal range, while $M$. spinosum is more northern extending from boreal to oroarctic zones in Eurasia. It is absent from western North America (Koponen 1973b, Steere 1974).

\section{Plagiomnium curvatulum}

Wyatt et al. (1993b) postulated, with good grounds, that Plagiomnium curvatulum most probably is an allopolyploid of two dioicous taxa, $P$. ellipticum $(\mathrm{n}=6)$ and $P$. elatum $(\mathrm{n}=6)$, or of the ancestor of the latter, $P$. "semielatum". Koponen (1971a) discussed at length on the characters of $P$. curvatulum (as $P$. medium ssp. curvatulum (Lindb.) T.J. Kop.) comparing it mainly to $P$. medium ssp. medium. He also mentioned the difficulty to distinguish especially the sterile shoots of $P$. curvatulum from $P$. ellipticum. The characters which $P$. curvatulum evidently inherited from $P$. ellipticum are dominant in the morphology of $P$. curvatulum. These include the small-sized teeth of the leaf margin, made of one cell (or even absent in sterile shoots), while $P$. elatum has teeth regularly with (1)2-3 cells per tooth (also on sterile shoots), and more irregularly arranged areolation of short elongate cells, while the areolation in P. elatum is made of regularly elongate, \pm rectangular cells often in clear diagonal rows from the costa towards the leaf border. The only morphological reminescences from $P$. elatum are shortly decurrent leaves in fertile shoots of $P$. curvatulum, and even these may be absent from leaves on sterile shoots. P. elatum has always rather broad and long-decurrent leaves. The character not present in any other of the related taxa of Plagiomnium sect. Rosulata is the yellow color of c. $3 / 4$ of the seta length in $P$. curvatulum.

\section{Plagiomnium drummondii}

Plagiomnum drummondii has a boreal, holarctic range in the boreal bioclimatic vegetation zone (McIntosh \& Newmaster, 2014a, Koponen \& Ignatova 2018). In Europe, it occurs rarely only in eastern part. It belongs to the section Plagiomnium and resembles most $P$. japonicum, both being larger in size and in having larger teeth of leaf margin than three other species of the section, $P$. acutum, . floridanum and P. cuspidatum. According to Harris (2008, fig. 4), $P$. drummondii $(\mathrm{n}=6)$ and $P$. japonicum $(\mathrm{n}=7)$ are sister taxa and form a sister group to the other species of the section Plagiomnium. On the basis of the chromosome numbers they hardly are a dioicous - monoicous species pair. According to Wyatt \& Odrzykoski (1998) "Plagiomnium japonicum is most genetically similar to $P$. drummondii, but these species are highly distinctive genetically from all other species". 


\section{Plagiomnium novae-zealandiae}

There seems not to be any suitable dioicous counterpart to synoicous Plagiomnim novaezealandiae. It has been given as synonymous with synoicous $P$. rostratum, which differs by non-decurrent leaves versus decurrent leaves in P. novae-zealandiae. Koponen (1982a) and Koponen and Sun (2017) hypotetized on the origin of synoicy in Plagiomnium sect. Rostrata. If it took place only once, in old Gondwanaland, this could explain the presence of synoicous $P$. novae-zealandiae in New Zealand and S Australia. If synoicy was borne only once but in SE Asia, the existence of synoicous P. novae-zealandiae is difficult to explain.

\section{Plagiomnium rostratum}

Synoicous Plagiomnium rostratum has a temperate - southern boreal range in North America and Europe. In Asia, it has some disjunct localities around the Lake Baikal area, in Western Himalaya and in Gansu - Sichuan provinces of China (range map in Koponen 1982a, c; Koponen 2014a). It differs from most other species of Plagiomnium section Rostrata by having non-decurrent leaves. The other Plagiomnium species with non-decurrent leaves are $P$. ellipticum (see above) and $P$. succulentum, but DNA characters show that $P$. succulentum is near the species of the genus Orthomnion (Koponen \& Sun 2017). Morphologically, the synoicous race of $P$. succulentum does not differ from its dioicous race (see above). The two other common dioicous species of the section Rostrata in Asia are P. integrum and $P$. maximoviczii. $P$. integrum has smaller but not sympatric range with the range of $P$. rostratum, has decurrent leaves, and larger elongate leaf cells, while the cells in $P$. rostratum are smaller and \pm isodiametric. $P$. integrum grows in many kinds of substrates (Koponen 1972a, 2014c, 2017, Koponen \& Norris 1983), while P. rostratum is a calcicole species. For these facts $P$. rostratum cannot be the synoicoius counterpart of dioicous $P$. integrum.

Plagiomnium maximoviczii has smaller leaf cells than $P$. rostratum, but the other characters such as the juxtacostal cells and the structure of leaf marginal teeth, and DNA characters suggest that it preferably is a pair of synoicous $P$. rhynchophorum (see above). In Harris's (2008, fig 2 and 4) cladograms $P$. rostratum is in the same glade with $P$. maximoviczii and $P$. novaezealandiae.

\section{Plagiomnium venustum}

Plagiomnium venustum is an endemic of the Pacific coastal areas of North America and it has no morphologically similar relatives.

\section{Species with only dioicous plants}

The family Mniaceae has 74 species (Koponen 2017), plus Cinclidium minutifolium (Koponen \& Ignatova 2018) and 69 of them are dioicous and four species are either dioicous or monoicous. The dioicous taxa, discussed with their monoicous pairs above are also included in the list below.

The dioicous taxa are grouped according to their distribution areas into phytogeographic groups or floristic elements. The phytogeographic code is that used in "Index Muscorum". The parenthesis indicate areas from which I have not seen correctly identified specimens.

\section{Continuously or disjunctively ranging holarctic taxa}

\section{Cinclidium Sw.}

arcticum (Bruch \& Schimp.) Schimp. - Am1 As1 (As2) Eur

latifolium Lindb. - Am1 As1 Eur

minutifolium Broth. - (Am 1) As 1 Eur 
Cyrtomnium Holmen

hymenophylloides (Hübener) T.J. Kop. - Am1 As1 As2 Eur

hymenophyllum (Bruch \& Schimp.) Holmen - Am1 As1 Eur

Mnium Hedw.

lycopodioides Schwägr. - Am1 As1-As5 Eur

blyttii Bruch \& Schimp. - Am1 As1 Eur

hornum Hedw. - Afr1 Am1 As5 Eur

spinosum (Voit) Schwägr. - Am1 As1-As3 As5 Eur

stellare Hedw. - Afr1 Am1 As1-As3 As5 Eur

thomsonii Schimp. - (Afr1) Am1 As1-As3 As5 Eur

Plagiomnium T.J. Kop.

ellipticum (Brid.) T.J. Kop. - (Afr1) Am1 Am6 As1-As3 As5 Eur

Pseudobryum (Kindb.) T.J. Kop.

cinclidioides (Hübener) T.J. Kop. - Am1 As1-As3 Eur

Rhizomnium (Broth.) T.J. Kop.

andrewsianum (Steere) T.J. Kop. - Am1 As1 Eur

gracile T.J. Kop. - Am1 As1 (As2) Eur

magnifolium (Horik.) T.J. Kop. - Am1 As1-As3 Eur

Mnium hornum was previously recorded from Japan and its neighbouring areas but it showed to be a different species, M. orientale (Wyatt et al. 1997). Accordingly, Mnium hornum occurs only in western N America and Europe and its neighbouring areas. M. spinosum is disjunctively Holarctic (see above). Plagiomnium ellipticum is bipolar occurring in S Chile and S. Argentina (Koponen 1971a).

\section{East Asia - NW North America}

Rhizomnium (Broth.) T.J. Kop. nudum (E.G. Britton \& R.S. Williams) T.J. Kop. - Am1 As1 As2

Trachycystis Lindb. flagellaris (Sull. \& Lesq.) Lindb. - Am1 As1 As2

A number of bryophytes occurring in SE Asia extend their range along the Aleutians to Alaska and Pacific N America. They are named as North Pacific or Beringian element.

\section{Western North America}

Leucolepis Lindb. acanthoneura (Hook.) W.C. Steere - Am1

Mnium Hedw. arizonicum J.J. Amann - Am 1

Plagiomnium T.J. Kop. insigne (Mitt.) T.J. Kop. - Am1

Rhizomnium (Broth.) T.J. Kop. glabrescens (Kindb.) T.J. Kop. - Am1

Mnium arizonicum differs from the species Pacific Coast element by that its range extends farther east in the inland and to Greenland (Koponen 1972b, McIntosh \& Newmaster 2014b).

\section{Eastern North America}

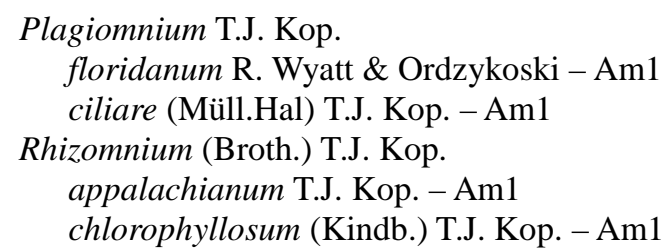


Plagiomnium ciliare, Rhizomnium applachianum and $R$. chlorophyllosum have rather wide ranges in coastal N America, the Appalachians and S Canada (Koponen 1971a, 1973a). As to Plagiomnium floridanum, see above. Rhizomnium chlorophyllosum was previously united collectively to the European $R$. punctatum (see Koponen \& Sun 2017).

\section{Europe}

Plagiomnium T.J. Kop.

affine (Funck) T.J. Kop. - Afr1 As5 Eur

elatum (Bruch \& Schimp.) T.J. Kop. - (Afr1 As5) Eur

undulatum (Hedw.) T.J. Kop.

var. undulatum - Afr1 Afr2 (Am1 Am6, introduced) As5 Eur

var. madeirense T.J. Kop \& Sergio - Afr1 Eur

Rhizomnium (Broth.) T.J. Kop.

punctatum (Hedw.) T.J. Kop.

var. punctatum - Afr1 As1 As5 Eur

var. hermanperssonii T.J. Kop. - Eur

The species of the European group are either restricted to Europe (Plagiomnium elatum) or occur also in Europe and neighbouring N Africa and Minor Asia ( $P$. affine, $P$. undulatum, Koponen 1971a, 1993). R. punctatum has disjunct localities in Central Siberia (Koponen \& Afonina 1993). In this connection it may be noted that in North America not a single species of Plagiomnium section Undulata occurs, except the introduced populations.

\section{Temperate to meridional SE Asia}

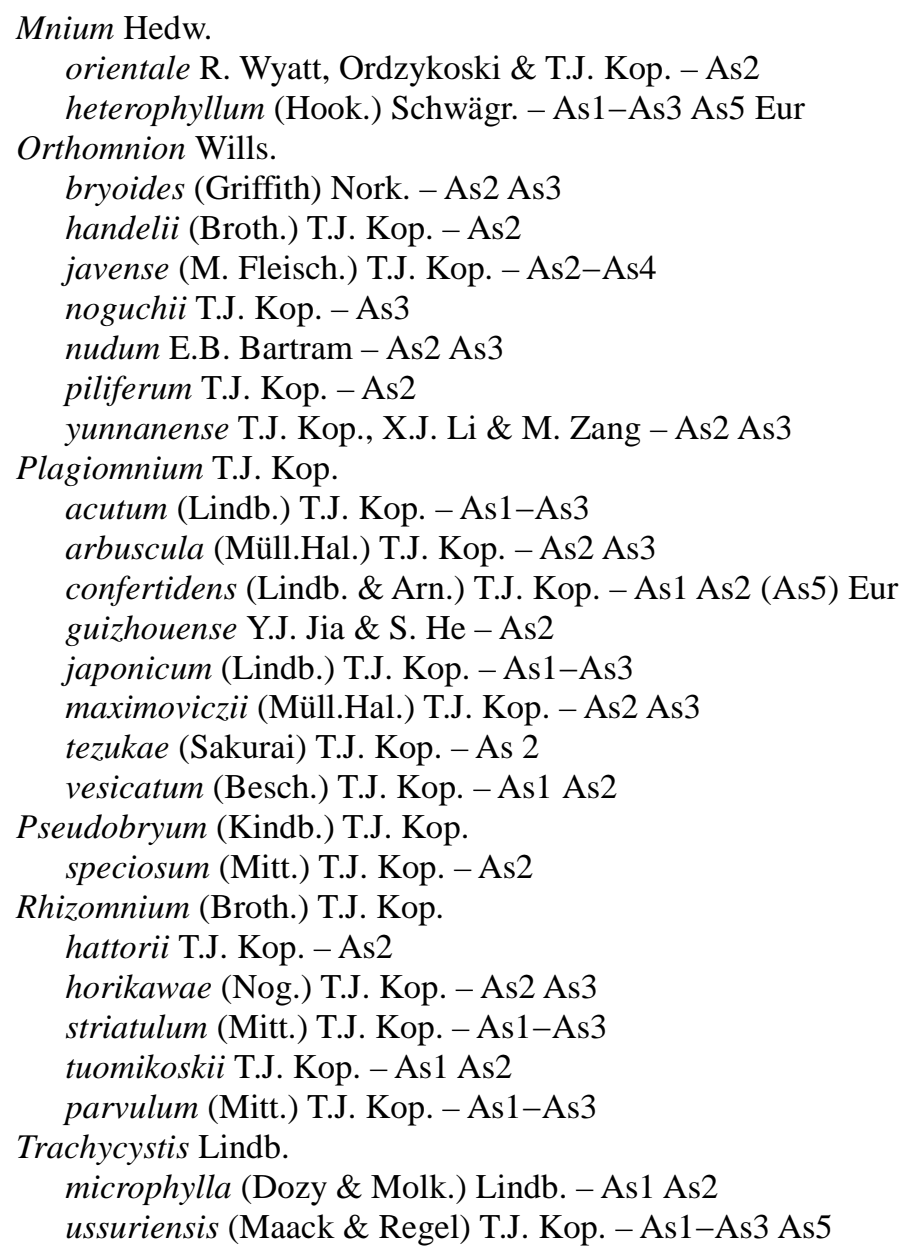


The Mniaceae is richest in species in temperate to meridional SE Asia. Most of the species belong to Himalayan-Japanese element ranging from Japan to the Himalayas. This element can be divided into several subelements (e.g. Koponen 2014a). A number of species range from the Himalayas to central China (Plagiomnium arbuscula, $P$. yunnanense, see below). Some of the taxa are endemics in limited areas, Pseudobryum speciosum in Japan, Orthomnion handelii in the Sino-Himalayas and Plagiomnium quizhouense in Quizhou Province in China. Mnium orientale (Koponen \& Ignatova 2018) and Plagiomnium vesicatum (Koponen 1972a, 2014a) occur in Japan and neighboring Korea and Russian Far East. Rhizomnium horikawae has the range disjunct between Taiwan and the Himalayas, similar to that of synoicous race of R. magnifolium.

Two of the species, Mnium heterophyllum and Trachycystis ussurienssis show old connection from SE Asia to Europe by ranging via the Himalayas to Caucasus area. Still more convincing of the earlier wider ranges are Trachycystis microphylla and T. flagellaris. They are known from Baltic amber born c. 44 million years ago (Frahm 2010). Plagiomnium confertidens has a rather northern range in Asia (Koponen \& Ignatova 2018) and could be included in the group of "Continuously or disjunctively ranging holarctic taxa" as well.

\section{Meridional to (sub)tropical SE Asia}

Orthomnion Wills.

elimbatum (Nog.) T.J. Kop. - As 4 Austr1

Plagiomnium T.J. Kop.

cordatum T.J. Kop. \& D.H. Norris - As4

elimbatum (M. Fleisch.) T.J. Kop. - As4

integrum (Bosch \& Sande Lac.) T.J. Kop. - As2-As4 Oc

succulentum (Mitt.) T.J. Kop. - As2-As4

Of these taxa, Plagiomnium integrum and $P$. succulentim extend their ranges from continental SE Asia to New Guinea (Koponen 2017). Plagiomnium cordatum is a New Guinean endemic, and Orthomnion elimbatum nearly so (Koponen \& Norris 1983). Plagiomnium elimbtum has an area from Java to continental Malaysia.

\section{Summary and conclusions}

\section{Prerequisities of species pairs}

1) One of the pairs is dioicous and the other is monoicous, and usually synoicous.

2) The chromosome number of the monoicous plant is double compared with dioicous plant.

3) The gametophytes of the monoicous plant are larger.

4) The leaf cells of the monoicous plant are larger.

5) The ranges of monoicous counterparts are in most cases wider than the ranges of dioicous counterpart and the ranges are sympatric. Most of them have similar habitat ecology.

\section{Characters observed not being affected by doubling of the chromosomes}

Leaf shape, leaf cell shape, structure of leaf marginal teeth, costa and leaf decurrency are similar in autopolyploid species pairs.

\section{Identification and taxonomic level}

The fertile plants of species pairs can always be separated by difference in the sexual condition. Moreover, perigonia of dioicous species differ from perichaetia of monoicous species, perigonial leaves having a different shape than perichaetial leaves. Even the non-fertile plants can be identified on the basis of the size of the plants and laminal cells, but not in all cases (Chapter 2.2.). Should these cryptic monoicous plants be separated at the specific or some other taxonomic level from the dioicous plants remains an open question (see below). 


\section{Addition to the nomenclature}

Jia and He (2015) transferred Orthomnion wui to Plagiomnium as P. wui (T.J. Kop.) Y.J. Jia \& S. He. Although its sporophyte has not been found, their decision was well founded. As discussed above, synoicous $O$. wui cannot be morphologically distinguished from dioicous Orthomnion yunnanense. I have seen a fruiting specimen of $O$. yunnanense (China. Yunnan, Gaolingshan region, 2015 J.R. Shevock 46507, W. Ma \& Y. Yao, in H). The capsule is similar to the capsules in Plagiomnium and the peristomes are complete. Thus, the combination of O. yunnanense to Plagiomnium is well founded. If the proposal by Ochyra et al. (2017) to conserve Plagiomnium against Orthomnion and Orthomniopsis is accepted, the other species of Orthomnion will suffer the same destiny as well.

Plagiomnium yunnanense (T.J. Kop., X.J. Li \& M. Zang) T.J. Kop., comb. nov.

Basionym: Orthomnion yunnanense T.J. Kop., X.J. Li \& M. Zang, Ann. Bot. Fennici 19: 73. 1982.

Acknowledgements: Dr. M. Ignatov (Moscow) and Dr. X. He (Helsinki) are thanked for forwarding literature not available to me. Mr. J.R. Shevock (San Francisco) is thanked for linguistic advice.

\section{References}

Blockeel T.L., Bosanquet S.D.S., Hill M.O. \& Preston C.D. (2014): Atlas of British \& Irish bryophytes. Vol. 2. The British Bryological Society \& Pisces publications, Berkshire, $652 \mathrm{pp}$.

Bowers M.C. (1969a): A cytotaxonomic study of the genus Mnium in Colorado. - Revue Bryologique et Lichénologique 36: 167-202.

- (1969b): Mnium saximontanum, a new diploid moss from the southern Rocky Mountains. - The Bryologist 72: 63-65.

- (1980): A cytotaxonomic classification of the Mniaceae (Bryophyta). - Lindbergia 6: 22-31.

Frahm J.-P. (2010): Die Laubmoosflora des baltischen Bernsteinwaldes. Weissdorn, Jena, 101 pp.

Frey W., Frahm J.-P., Fischer E. \& Lobin W. (2006): The liverworts, mosses and ferns of Europe. Harley Books, Colchester, xv, $512 \mathrm{pp}$.

Fritsch R. (1982): Index to plant chromosome numbers - bryophyta. - Regnum Vegetabile 108: i-xiv, 1-268.

Harris E.S.J. (2008): Paraphyly and multiple causes of phylogenetic incongruence in the moss genus Plagiomnium (Mniaceae). - Taxon 57: 417-433.

Jankowiak K., Rybarczyk A., Wyatt R., Odrzykoski I., Pacak A. \& Szweykowska-Kulinska Z. (2005): Organeller inheritance in the allopolyploid moss Rhizomnium pseudopunctatum. - Taxon 54: 383-388.

Jia Y.-J. \& He S. (2014): Plagiomnium quizhouense Y.J. Jia \& S. He sp. nov. (Mniaceae) found in southwestern China. - Journal of Bryology 36: 291-294.

- (2015): Plagiomnium wui (Mniaceae), a new combination from Hubei, China. - Novon 23: 494-498.

Kabiersch W. (1936): Studien über die ostasiatischen Arten einiger Laubmoosfamilien (Mniaceae Bartramiaceae). - Hedwigia 76: 1-94.

Koponen T. (1967): Biometrical analysis of a mixed stand of Mnium affine Funck and M. medium B.S.G. Annales Botanici Fennici 4: 67-73.

- (1968a): Generic revision of Mniaceae Mitt. (Bryophyta). - Annales Botanici Fennici 5: 117-151. (Reprinted in: Duncan, T. \& Stuessy, T. F. [eds] (1985): Cladistic theory and methodology. Van Nostrand Reinhold Company, New York, pp. 103-137.

- (1968b): The moss genus Rhizomnium (Broth.) Kop., with description of R. perssonii, species nova. Memoranda Societatis pro Fauna et Flora Fennica 44: 33-50.

- (1971a): A monograph of Plagiomnium sect. Rosulata (Mniaceae). - Annales Botanici Fennici 8: 305-367.

- (1971b): A report on Rhizomnium (Mniaceae) in Japan. - Journal of the Hattori Botanical Laboratory 34: 365390.

- (1971c): Keys for the Mniaceae in Taiwan. - Annales Botanici Fennici 8: 297-304.

- (1972a): The East Asiatic species of Plagiomnium sect. Rostrata (Bryophyta). - Acta Botanica Fennica 97: 129.

- (1972b): Notes on Mnium arizonicum and M. thomsonii. - Lindbergia 1: 161-165.

- (1973a): Rhizomnium (Mniaceae) in North America. - Annales Botanici Fennici 10: 1-26.

- (1973b): Mnium spinosum in North America. - Annales Botanici Fennici 10: 102-103.

- (1974a): A guide to the Mniaceae in Canada. - Lindbergia 2: 160-184.

- (1974b): A preliminary report on the Mniaceae in Japan. II. - Hikobia 7: 1-19. 
- (1979a): On the taxonomy and phytogeography of Mnium Hedw. s. str. (Musci, Mniaceae). - Abstracta Botanica 5 (Suppl. 3): 63-73.

- (1979b): A synopsis of Mniaceae (Bryophyta). I. South and Central American taxa. - Journal of the Hattori Botanical Lababortory 46: 155-161.

- (1980a): A synopsis of Mniaceae (Bryophyta). II. Orthomnion. - Annales Botanici Fennici 17: 35-55.

- (1980b): A synopsis of Mniaceae (Bryophyta). IV. Taxa in Europe, Macaronesia, NW Africa and the Near East. - Annales Botanici Fennici 17: 125-162.

- (1981a): Miscellaneous notes on Mniaceae (Bryophyta). VIII. Verification of the vouchers of some chromosome number reports. - Annales Botanici Fennici 18: 73-82.

- (1981b): A synopsis of Mniaceae (Bryophyta). VI. Southeast Asian taxa. - Acta Botanica Fennica 117: 1-34.

- (1981c): A synopsis of Mniaceae (Bryophyta): V. Taxa in Africa South of the Sahara. - Annales Botanici Fennici 18: $105-111$.

- (1982a): The family Mniaceae in Australasia and the Pacific. - Journal of the Hattori Botanical Laboratory 52: 75-86.

- (1982b): Miscellaneous notes on Mniaceae (Bryophyta). XI. Distribution of Plagiomnium rostratum. Memoranda Societatis pro Fauna et Flora Fennica 58: 17-20.

- (1993): Miscellaneous notes on the Mniaceae (Bryophyta). XVI. Plagiomnium undulatum (Hedw.) T. Kop. in Ethiopia. - Bulletin du Jardin Botanique de l'État Belgigue 62: 397-402.

- (2007): Orthomnion wui (Mniaceae, Musci), a new species from Hubei Province, China. - Annales Botanici Fennici 44: 376-378.

- (2014a): Miscellaneous notes on the Mniaceae (Bryophyta). XVII. Rejecting old or unreliable records: Plagiomnium cuspidatum, $P$. medium, $P$. rostratum, $P$. venustum, $P$. vesicatum and $P$. acutum in China. - Acta Bryolichenologica Asiatica 5: 113-127.

- (2014b): A synopsis of Mniaceae (Bryophyta). IX. Taxonomy, habitats, substrates and ranges of the species of Rhizomnium. - Acta Bryolichenologica Asiatica 5: 85-111.

- (2014c): Bryophyte flora of Hunan Province, China. 18. Mniaceae subfam. Mnioideae (Musci). - Acta Bryolichenologica Asiatica 5: 39-72.

- (2015): Hentolehväsammal Suomessa. [Rhizomnium gracile in Finland.] - Bryobrotherella 18: 99-105

- (2017): A synopsis of the Mniaceae (Bryophyta). X. Malesian taxa, with a world list of the taxa in Mniaceae. Acta Bryolichenologica Asiatica 7: 205-227.

Koponen T. \& Afonina O. (1992): Miscellaneous notes on Mniaceae (Bryophyta). XV. Genus Rhizomnium in the Russia east of Ural Mts. - Bryobrothera 1: 245-250.

Koponen T. \& Ignatova E.A. (2018): [Family] Mniaceae Schwägr. - In: Ignatov M.S. (ed.), Moss Flora of Russia. KMK Scientific Press Ltd., Moscow. Pp. 439-517.

Koponen T. \& Li X.-J. \& Zang M. (1982): Miscellaneous notes on Mniaceae (Bryophyta). XIII. Orthomnion yunnanense, species nova. - Annales Botanici Fennici 19: 73-74.

Koponen T. \& Nils son E. (1978): Flavonoid patterns and species pairs in Plagiomnium and Rhizomnium (Mniaceae). - Bryophytorum Bibliotheca 13: 411-425.

Koponen T. \& Norris D.H. (1983): Bryophyte flora of the Huon Peninsula, Papua New Guinea. II. Mniaceae (Musci). - Annales Botanici Fennici 20: 31-40.

Koponen T. \& Sun Y. (2017): Preliminary study on phylogenetic position and delimitation of the ciliate arthrodontous genera of the moss family Mniaceae. - Journal of Bryology 39: 23-38.

Lowry R.J. (1948): A cytotaxonomic study of the genus Mnium. - Memoirs of the Torrey Botanical Club 20(2): $1-42$.

McIntosh T.T. \& Newmaster S.G. (2014a): Plagiomnium T. J. Koponen. - In Flora of North America North of Mexico, vol. 28. Bryophyta. Part 2. Flora of North America Editorial Committee, New York, Oxford University Press: 229-235.

- (2014b): Mnium Hedwig. In: Flora of North America North of Mexico, vol. 28. Bryophyta. Part 2. Flora of North America Editorial Committee, New York, Oxford University Press: 223-228.

Mogensen G.S. (1973): A revision of the moss genus Cinclidium Sw. (Mniaceae Mitt.). - Lindbergia 2: 49-80.

Noguchi A. (1989): Illustrated moss flora of Japan. Supplemented by Zennoske Iwatsuki, Fasc. 3. Hattori Botanical Laboratory, Nichinan: pp. 493-742, i-vi.

Ochyra R., Bednarek-Ochyra H. \& Plášek V. (2017): Proposal to conserve the name Plagiomnium against Orthomnion and Othomniopsis (Bryophyta: Mniaceae). - Taxon: 66: 1218-1220.

Pineiro R., Popp M., Hassel K., Listl D., Westgaard K.B., Flatberg K.I., Stenøien H.K. \& Brochman C. (2012): Circumarctic dispersal and long-distance colonization of South America: the moss genus Cinclidium. - Journal of Biogeography 39: 2041-2051.

Söderström L. [ed.] (1998): Preliminary distribution maps of bryophytes in northwestern Europe. Mossornas vänner, Trondheim, $69 \mathrm{pp}$.

Steere W.C. (1974): The occurrance of Mnium spinosum in North America. II. - The Bryologist 77: 79-82. 
Wettstein F. von (1924): Morphologie und Physiologie des Formenwecksels der Moose auf genetischer Grundlage. - Zeitschrift für Induktive Abstammungs- und Vererbungslehre 33: 1-236.

- (1938): Experimentelle Untersuchungen zum Artbildungsproblem. I. Zellgrössenregulation und Fertilwerden einer polyploiden Bryum-Sippe. - Zeitschrift für Induktive Abstammungs- und Vererbungslehre 74: 34-53.

- (1942): Über einige Beobachtungen und experimentelle Befunde bei Laubmoosen. - Berichte der Deutschen Botanischen Gesellschaft 60: 394-414.

Wettstein F. von \& Staub J. (1942): Experimentelle Untersuchungen zum Artbildungsproblem. III. Weitere Beobachtungen an polyploiden Bryum-Sippen. - Zeitschrift für Induktive Abstammungs- und Vererbungslehre 80: 271-280.

Wyatt R. (1985): Chemosystematics of the Mniaceae. I. Identities of Lowry's species pairs. - Monographs in Systematic Botany from the Missouri Botanical Garden 11: 187-194.

Wyatt R., Ireneusz J., Odrzykoski I.J. \& Stoneburner A. (1993a): Isozyme evidence proves that the moss Rhizomnium pseudopunctatum is an allopolyploid of $R$. gracile $\times R$. magnifolium. - Memoirs of the Torrey Botanical Club 25: 21-35.

Wyatt R. \& Odrzykoski I.J. (1998): On the origins of the allopolyploid moss Plagiomnium cuspidatum. - The Bryologist 101: 263-271.

- (2012): Plagiomnium floridanum sp. nov. (Mniaceae), a new moss from the southeastern United States. - The Bryologist 115: 527-535.

Wyatt R., Odrzykoski I. J., \& Koponen T. (1997): Mnium orientale sp. nov from Japan is morphologically and genetically distinct from M. hornum in Europe and North America. - The Bryologist 100: 226-236.

Wyatt R., Odrzykoski I.J. \& Stoneburner A. (1992). Isozyme evidence of reticulate evolution in mosses: Plagiomnium medium is an allopolyploid of P. ellipticum $\times$ P. insigne. - Systematic Botany 17: 532-550.

- (1993a): Isozyme evidence proves that the moss Rhizomnium pseudopunctum is an allopolyploid of $R$. gracile $\times$ R. magnifolium. - Memoirs of the Torrey Botanical Club. 25: 21-35.

- (1993b): Isozyme evidence regarding the origins of the allopolyploid moss Plagiomnium curvatulum. Lindbergia 18: 49-58.

- (2013): Isozyme evidence regarding the nature of polyploidy in the moss genus Cinclidium (Mniaceae). - The Bryologist 116: 229-237.

Wyatt R., Odrzykoski I.J., Stoneburner A., Bass H.W. \& Galau G.A. (1988). Allopolyploidy in bryophytes: Multiple origins of Plagiomnium medium. - Proceedings of the National Academy of Sciences of the United States of America 85: 5601-5604.

Author's address: Timo Koponen, Finnish-Chinese Botanical Foundation, Mailantie 109, FI-08800 Lohja, Finland;

Finnish Museum of Natural History, Botany Unit (Bryology), P.O. Box 7, FI-00014

University of Helsinki, Finland.

E-mail: timo.koponen@helsinki.fi 